\title{
PERFORMANCE OF A POLY-GREENHOUSE WITH DIFFERENT VENTILATION GAPS UNDER FAYOUM CLIMATIC CONDITIONS
}

\author{
H. S. Abdel-Galil*
}

ABSTRACT

Four different poly-greenhouse models were compared with the open field condition at El-Azab village, Fayoum, Egypt from $18^{\text {th }}$ January to $30^{\text {th }}$ July, 2010. Production of chili pepper in greenhouses was an effective way of increasing the yield per unit area and enhancing its quality. Therefore, different sized poly-greenhouse ventilation gaps with $25 \%$ shade net and UV stabilized plastic film sheet materials were used. The thermal performance of the greenhouse models and their effects on the growth rate and yield of chili pepper were investigated.

The obtained results indicated that the air temperature in the open field condition was lower than in the poly-greenhouse treatments throughout the growth period of chili peppers bushes. Production of chilli pepper in greenhouse was an effective way of increasing the yield per unit area and enhancing the quality. Poly-greenhouse model with ventilation gaps in the triangular roof and four sidewalls (T3) was found more suitable for better plant growth and yield of chili pepper than those with the other ventilation gaps in poly-greenhouse models and open field condition.

\section{INTRODUCTION}

I $\mathrm{t}$ is possible to produce horticultural crops all year round in Egypt, both in the open field condition and in the greenhouses, even during the extremely cold winter. Horticultural crops production in greenhouses is intended to increase farmers' incomes. Thus, we should keep in mind that a higher investment is intended to set up a greenhouse. Fayoum depression has a private climatic condition, where, the great gap data between minimum and maximum ambient temperature during the 24 hours of day, especially during the winter season. Greenhouse is a climate controlled; it can provide an excellent controlled environment for plant production.

*Assoic. Prof. of Agric. Eng., Fac. of Agric. Fayoum University. 
The day temperature of $43{ }^{\circ} \mathrm{C}$ during April in the plastic-greenhouse caused premature flowering and fruit drops (Maeglsson and Adata, 1977). Thus, of all the climatic factors affecting vegetable production, temperature is considered very important because it affects growth and development of economic parts, flowering, pollination, fruit set, quality of produce, seed storage, seed dormancy and occurrence of disease and pests (Singh, 1997). The control of air temperature in the greenhouse depends on the ventilation during the day-time. Also, the amount of solar radiation transmitted into the greenhouses during the day-time was different in each type of structure being affected mainly by the covering material. The transmittance rate of solar radiation into the glasshouse was $64.7 \%$, but it ranged from $61.3 \%$ to $56.4 \%$ into the plastic-house, depending on the type of plastic material (Kwon and Chun, 1999). Increasing the ventilation rate reduces temperature gradients, but enhances plant transpiration and could also, contribute to water stress. Stronger shading reduces the transpiration demand, but it proportionally reduces photosynthetic rate, and consequently, the expected yield (Kittas et al., 2003). One of the most aspects of greenhouse design is to provide a covering with controlled differences between the transparency in the solar radiation band and the terrestrial thermal radiation band for the purpose of either raising or lowering the temperature inside the greenhouse (Wikipedia, 2007). The use of green or black shade net sheets as a covering material for greenhouses in summer season under Mediterranean climatic zone enhanced the germination percentage and the rate of vegetative growth for horticultural crops (Abdel-Galil and Abo-Habaga, 2007). Increasing of shading ratios caused to decrease the temperatures inside the greenhouses models during the day time from sunrise to sunset, and the thermal equilibrium was obtained during the night hours. All shading ratios caused to increase the relative humidity inside the greenhouse (Adbel-Galil and Mourad, 2009).

The literature on "peppers" contains a confusing labyrinth of names (chile, chili and chilli) with various derivations and slight nuances of meaning. Etymologically, the word "chile" is derived from the Aztec language, and refers to Capsicum peppers in Central America and in several parts of southwestern United States (Smith et al., 1987). The word "chili" is thought to be the anglicized form of "chile" and now 
denominates pungent types of Capsicum peppers in the United States. Similarly, the word "chilli" is used in the Middle Eastern and Asian countries in connection with pungent forms. Major producers of chilli pepper include Asia, Africa, Europe, Latin and North America (Anonymous, 2003). Chili pepper is an important vegetable and spice crop worldwide, that is produced and consumed as fresh or processed. It is found throughout the world and plays a significant socio-economic role (Sanogo, 2003). Chili peppers (Capsicum spp.) are a highly valued crop in the world, as they are an important ingredient in a wide variety of cuisines, good source of vitamins and minerals, and have antimicrobial properties (Bagga et al., 2010).

The best temperatures for germination horticultural seeds were between $20^{\circ} \mathrm{C}$ to $30^{\circ} \mathrm{C}$ dependant on the type of substrates used (Garcia, 1994). The production of chili pepper under greenhouse could be a good opportunity to produce high yields of supreme quality, rather than open field conditions. The level of productivity under the greenhouse is about 5 times the fruit harvested under the open field condition (Zapata et al., 2002). Chili peppers are warm-season crops, sensitive to freezing temperatures at any growth stage. The rate of seed germination decreases rapidly when soil temperatures are below $25^{\circ} \mathrm{C}$ with germination below $20^{\circ} \mathrm{C}$ exceedingly slow. Day temperatures of $23.9^{\circ} \mathrm{C}$ to $29.4^{\circ} \mathrm{C}$ with night temperatures about $10{ }^{\circ} \mathrm{C}$ to $15.6{ }^{\circ} \mathrm{C}$ are ideal for plant growth. Although tolerant of temperatures of about $37.8{ }^{\circ} \mathrm{C}$, such extreme conditions can reduce effective pollination, fruit set and yield (Smith et al., 2005). Chili pepper fruit should be picked when they turned completely red, and yields should be reported on a fresh weight basis. Under optimum conditions, it takes about 55 to 60 days after flowering for the first fruits to fully ripen (Berke and Gniffke, 2006). Datil pepper (Capsicum chinense var.) is well known throughout the famous St. Augustine hot pepper, where it has cultivated since the $1700_{\mathrm{s}}$. These plants were harvested 10 times: 6 times from 8 June to 31 July at 2.2 plants $/ \mathrm{m}^{2}$ and 4 times at 0.5 plant $\mathrm{m}^{2}$ from 6 Oct., 2006 to 3 Jan., 2007. The marketable fruit numbers $/ \mathrm{m}^{2}$ were similar between densities, but significantly different between selections and ranged from 234 to 392 fruit / m (Shaw et al., 2008).

Producers usually don't use modern planting technology; these are the main reasons because they have low yields and products of poor quality. 
The objective of present study was to study the effect of temperature in the poly-greenhouse models with different ventilation gaps in comparison with the open field on the performance of growth rate and yield of chili pepper under Fayoum depression climatic conditions.

\section{MATERIALS AND METHODS}

The experimental work was carried out under ploy-greenhouse models having different ventilation gaps (without temperature, humidity and light control) and in an open field condition.

\section{Specifications of different greenhouse models structures:}

Four gable roof shape poly-greenhouse models were constructed and oriented to face east-west direction. These models were made of water galvanized pipes of $2.5 \mathrm{~cm}$ diameter. The ventilation system was a natural, where, there are two doors in the narrow sides of each model, which covered with UV-film sheets and kept open during the day-light and closed at night, especially with the greenhouse model fully covered with white UV- film sheets. A single layer of transparent polyethylene treated against ultra violet radiation effect (200 micron thickness and $0.96 \mathrm{~g} / \mathrm{cm}^{3}$ density) and black screen shade net sheets of $25 \%$ were used for covering the greenhouse models. During the experimental periods, all the greenhouse models were kept under the same environmental conditions. The diagrammatic representation of the greenhouse models are shown in Figure (1), and the treatments followed and their specifications are shown in Table (1).

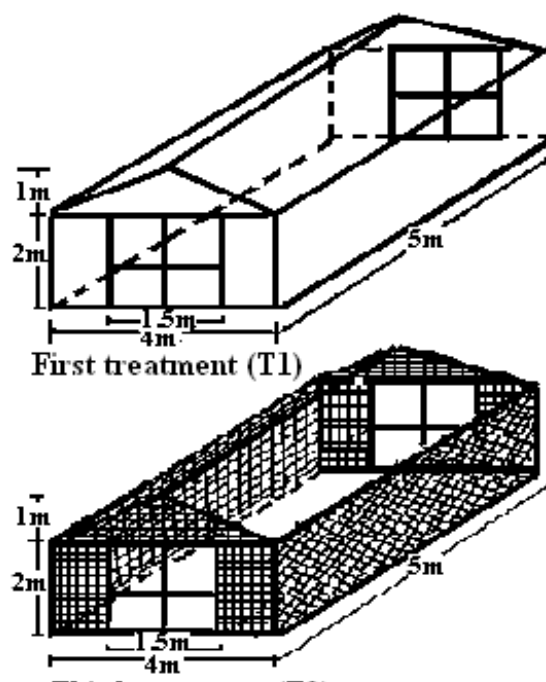

Third treatment (T3)

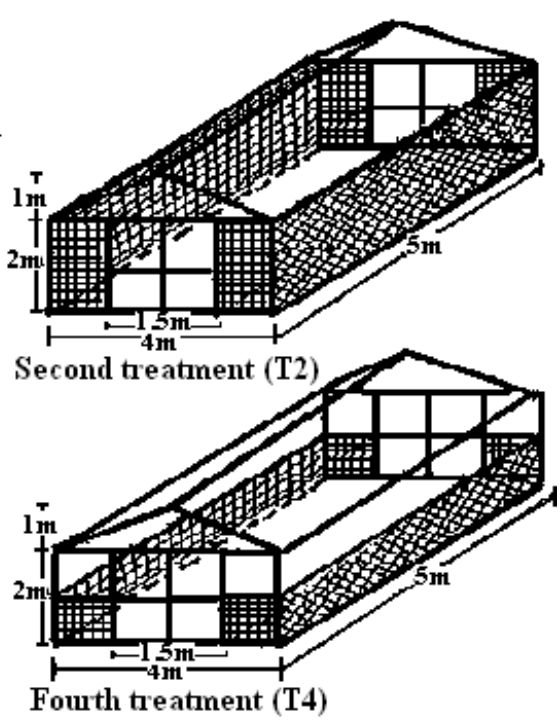

Fouth treatment (T4)

Fig. (1): Diagrammatic r epresentation of the greenhouse models. 
Table (1): The greenhouse treatments and their specifications

\begin{tabular}{|c|l|}
\hline Treatments & \multicolumn{1}{|c|}{ Specifications } \\
\hline T1 & $\begin{array}{l}\text { Fully covered with white UV- film sheets (both sides of } \\
\text { the door kept open for ventilation during the day-time). }\end{array}$ \\
\hline T2 & $\begin{array}{l}\text { Four sides covered with 25\% black screen shade net } \\
\text { sheet and the entire roof covered with UV- film sheets. }\end{array}$ \\
\hline T3 & $\begin{array}{l}\text { Four sides and triangular structured roof on both sides } \\
\text { covered with 25\% black screen shade net sheet and the } \\
\text { parallelograms of the structured roof covered with UV- } \\
\text { film sheets. }\end{array}$ \\
\hline T4 & $\begin{array}{l}\text { The entire roof and half the portion of the four sides from } \\
\text { the top covered with white UV- film sheets and the } \\
\text { remaining half covered with 25\% black screen shade net } \\
\text { sheets. }\end{array}$ \\
\hline T5 & Open field condition (control). \\
\hline
\end{tabular}

\section{Measurements of meteorological conditions:}

Global solar radiation $\left(\mathrm{I}, \mathrm{W} / \mathrm{m}^{2}\right)$, air temperature $\left(\mathrm{T},{ }^{\circ} \mathrm{C}\right)$, light intensity (L, lux), and relative humidity ( $\mathrm{Rh}, \%$ ) were measured daily from sunrise to sunset inside and outside the greenhouse models as follows:

2.1. Solar radiation: The solar radiation intensity was measured daily every one hour interval only outside the greenhouse models, using a data acquisition system with an accuracy of $0.1 \mathrm{~W} / \mathrm{m}^{2}$.

2.2. Air temperature: The air temperatures were measured daily every two hours interval outside and inside the greenhouse models. Inside each model, there are three measured positions (Center $\left(\mathrm{T}_{\mathrm{i} 2}\right)$ and 1.25 meter far from the greenhouse doors $\left(\mathrm{T}_{\mathrm{i} 1}\right.$ and $\left.\mathrm{T}_{\mathrm{i} 3}\right)$ ). The measuring sensors were put above the ground by one meter. A thermocouple recordable was used for measuring (VE 310, with an accuracy of $0.1{ }^{\circ} \mathrm{C}$ ).

2.3. Relative humidity: A digital thermo-hygrometer with measuring range of $2 \%-98 \%$ was used to record the relative humidity ratio inside the greenhouse models.

2.4. Light intensity: A digital Luxmeter (unit: lux, measuring 1-150000 lux, with an accuracy of 1 lux), was used to record the light intensity inside and outside the greenhouse models. The light intensity was 
measured every two hours.

\section{Seeds germination, cultivation and plant harvesting:}

3.1. Indoor germination: Hybrid variety (GAZELLE F1) of chili pepper seeds were sowed into 96-cell seedling trays (with holes at their bottom) filled with 1:1:1 (v: v: v) compost: peat moss: perlite on $18^{\text {th }}$ January, 2010. Chili pepper seeds were placed on the surface of the growing medium in each seedling tray, and covered with $1-\mathrm{cm}$ of the growing medium. Then, the seeds were watered until the growing medium is moist to the touch. After that, the seedlings were germinated in growth chamber with temperature at $21^{\circ} \mathrm{C} / 18^{\circ} \mathrm{C}$ day/night and $8 \mathrm{~h}$ light. All the seedling trays were under the same conditions in terms of type of sowing method, irrigation and the other agricultural processes.

3.2. Seedlings cultivation and growing: After six weeks of seeds sowing, seedlings were reached the five-leaf stage and then, they were transplanted to grow under four poly-greenhouse models having different ventilation gaps and in an open field condition. Each plot measured 5-m $\times 3$-m having two raised beds (4-m long and 1.2-m wide) with two rows of plants per bed; in-row plant spacing $30-\mathrm{cm}$ and $1.2-\mathrm{m}$ between rows. All experimental treatments (irrigation, fertilization and crop protection, etc.,) were under the recommended agricultural processes (Nicole et al., 2008). Under these conditions, all branches, side shoots (lateral) and fruit remained on the chili pepper plants. Observations on plant height, stem diameter, leaf area, length of main stem, canopy width, length of first branch node, rate of aborted branches, canopy area, light interception rate and dry matter weight were recorded on randomly selected 10 plants in each plot. Canopy area and light interception rate were calculated using the following formula of Kwon and Chun (1999):

Canopy area $(\%)=$ canopy area per plant $\left(\mathrm{cm}^{2}\right) /$ plant placing (area allocated to each plant) $\left(\mathrm{cm}^{2}\right) \times 100$

Light interception rate $(\%)=100-($ Light intensity at half the bush height / Light intensity above the canopy) $\times 100$

3.3 Harvesting: Chili pepper seedlings were planted in $1^{\text {st }}$ March (2010) and harvested 4 times from $15^{\text {st }}$ May to $30^{\text {th }}$ of July. The first fruits may be ready to harvest 70 to 80 days after transplanting. Chili pepper is hand harvested into baskets, and then taken for determining their characteristics (fruit length, fruit diameter, dry/fresh rat and vitamin $\mathrm{C}$ content). 


\section{RESULTS AND DISCUSSIONS}

Experimental work was carried out at El-Azab village, which is located at $5 \mathrm{~km}$ south of Fayoum city, Egypt, (Latitude of $29.18^{\circ} \mathrm{N}$ and Longitude angle of $30.3^{\circ}$ ). The obtained data were collected through the period of $16^{\text {th }}$ January to $30^{\text {th }}$ July, 2010.

\section{Solar radiation intensity:}

The amount of solar radiation (I) transmitted into the greenhouse models during the day-time was different in each structure of the models, being affected mainly by their ventilation gaps. The hourly average solar radiation transmitted into the greenhouse models on April (2010) is shown in Figure (2). Level of solar radiation under the greenhouse models changes according to the angle of the sun in different months and the type of covering materials. Therefore, the result measured on April (2010) does not represent the solar radiation through all the experimental periods. It's clear that, the hourly average solar radiation available inside the four greenhouses reached the maximum magnitude at and around noon time and it was less compared with the hourly average solar radiation flux incident on the outside horizontal surface. The transmittance rate of solar radiation was higher in the greenhouse models fully covered by white plastic UV film sheets and that covered with $25 \%$ black screen shade net sheets in the half portion of the four sides from the bottom (T1 and T4) than the others two greenhouses (T2 and T3). In this study, because the plants were in the first stage of growth (poor leaves and steams) therefore, more than one half of the solar radiation intensity received by the greenhouse was converted into thermal energy caused in excess of the interior air temperature than the expected. Not only is a high rate of solar transmittance important in winter vegetable production, but the solar spectral quality is also an important factor determining vegetable quality.

Figure (3) shows the air temperatures inside and outside the greenhouse models and the solar radiation intensity behaviors during the experimental months. The plotted data were taken as the average of data, which collected from sunrise to sunset. It's clear that, as solar intensity increased, the higher trend of different temperatures increased. It was also; found that ambient air temperature was always less than that in the poly-greenhouse models, but it gradually increased during the months of May to July than in the second and third treatments (T2 and T3). 


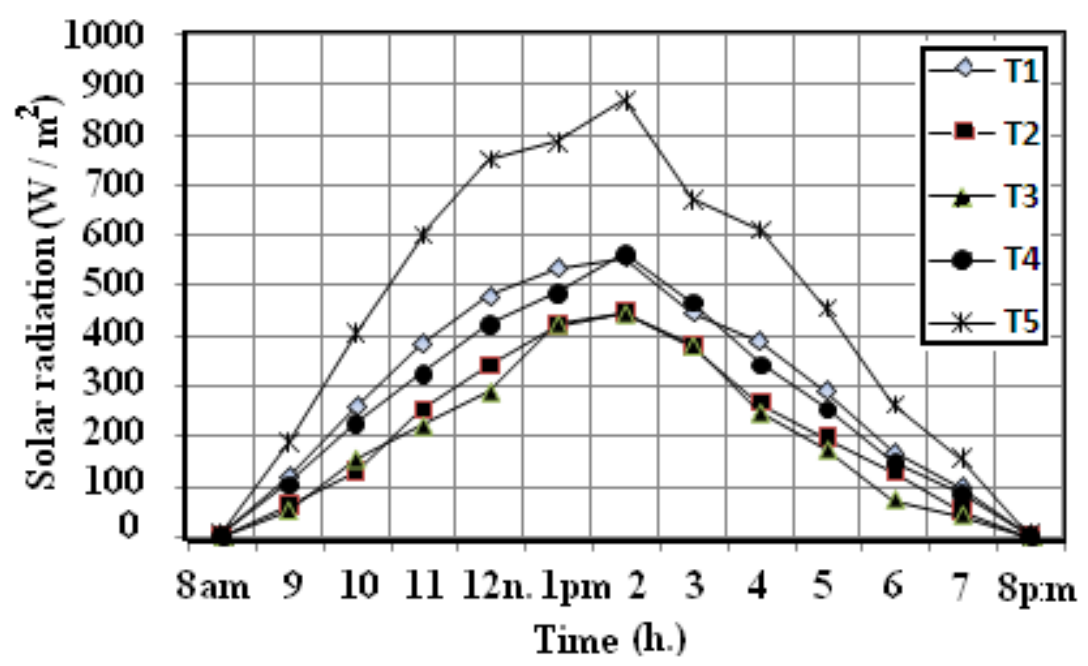

Fig. (2): Diunal variation ${ }^{*}$ in transmission of solar energy in different poly-greenhouse models for the month of April, 2010.

* Measured at hight of $1.5 \mathrm{~m}$ in greenhouses and outdoor

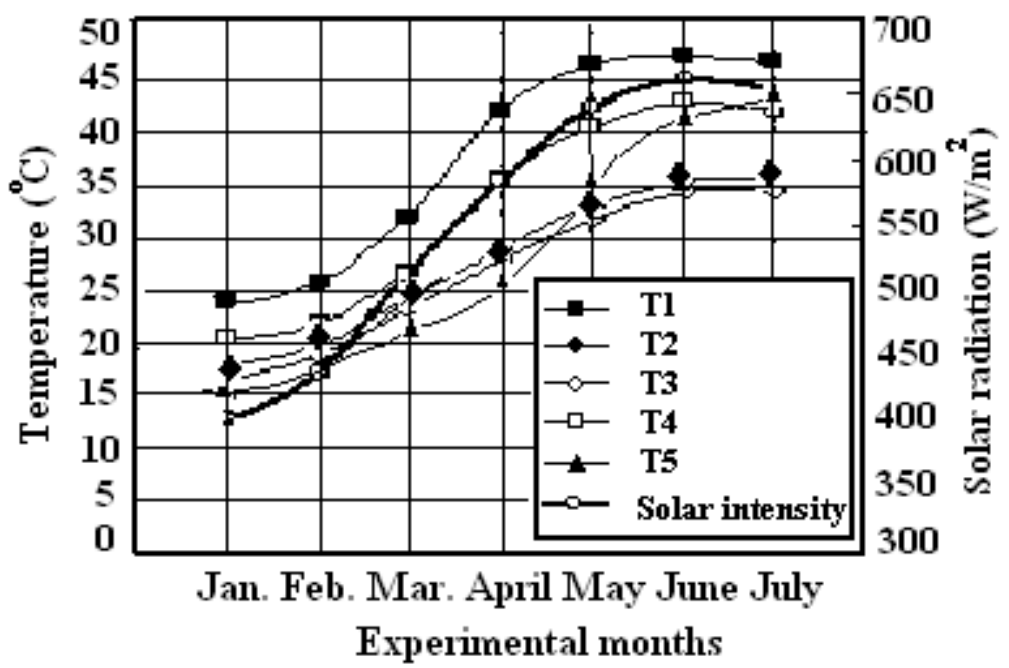

Fig. (3): Temperature and solar radiation trends duing the experimental period.

2. Air temperature inside the greenhouse models:

Control of air temperature in the greenhouses depends on the ventilation during the day-time. Thereby, different ventilation gaps in the polygreenhouse models influenced their inside air temperature. Figure (4) 
shows the recording data for each treatment, which represent the average recording data during the day (24 hr.) for the month of April (2010). It's clear that, air temperature in the open field condition was lower than in the poly-greenhouse models throughout the growth period of the chilli bushes (winter months). It was also; found that inside air temperature of the second and third treatments (T2 and T3) was higher than in the open field, but less than that in the other greenhouse treatments (T1 and T4) during the period from $8 \mathrm{am}$ to sunset. Though the temperature was found higher in treatments T2 and T3 than in the open field condition, it had contributed to higher yield in both of them. On the other hand, approximately, all temperatures data were near through the night hours (from $8 \mathrm{pm}$ to sunrise). It's clear that, the maximum differential temperature was found with temperature inside the first treatment (T1), while the minimum differential temperature was appeared with the temperature of the open field (T5) and the other temperatures differences in between both of them. These differences reflect the differences in the heat balance resulting from the short-wave radiation transmitted into the greenhouse models and longwave radiation transferred out (Giacomelli and Willim, 2005). The higher temperature at 2-pm in the poly-greenhouse treatments was due to trapping of short wave radiations by the greenhouse models and partially closed greenhouses.

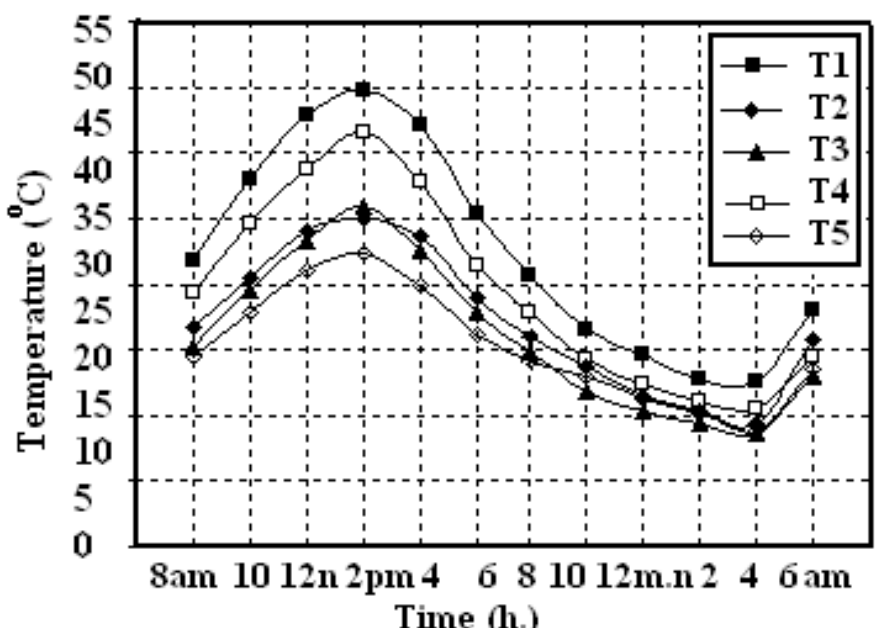

Fig. (4): Diunal variation * in air temperature outside and inside the poly-greenhouse models duing the day-time of April, 2010.

* Air temperature was measured at a height of $1.5 \mathrm{~m}$ above the soil surface. 


\section{Relative humidity inside the greenhouse models:}

The diurnal variation in relative humidity in the different sized polygreenhouse ventilation gaps is shown in Figure (5), during the day time of $15^{\text {th }}$ April, 2010. It's clear that, the relative humidity in T1 (greenhouse fully covered with white UV- film sheets) was lower than that in the others poly-greenhouse treatments and open field condition during the day-time from sunrise to sunset, but it gradually increased during the night-time than in the open field treatment (T5). When the doors were closed at night, relative humidity was almost stable, while it fluctuated during the day-time (from sunrise to sunset) when the doors were open. When the greenhouses doors were and ventilation ceased, the relative humidity tended to increase slowly, and then remain stable.

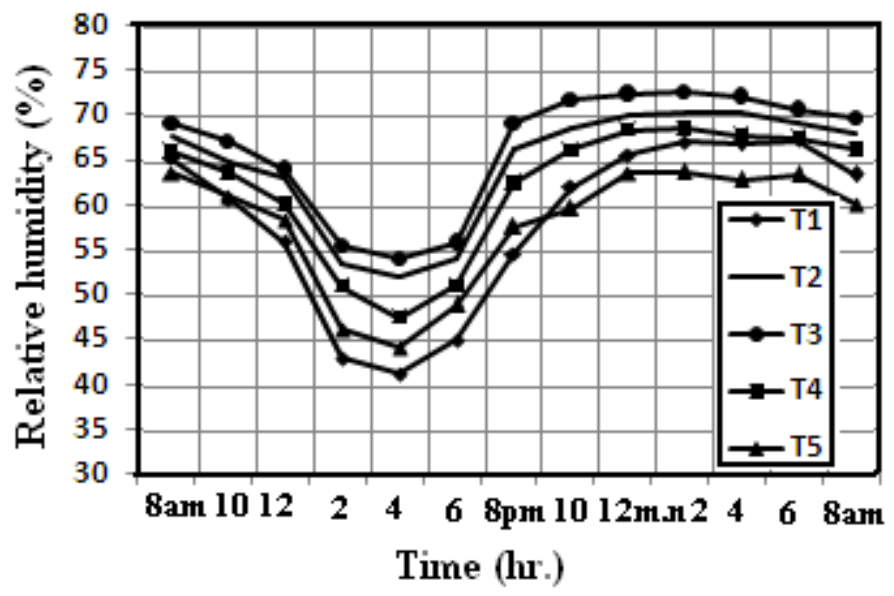

Fig. (5) : Diumunal variation ${ }^{\star}$ of relative humidity inside the greenhouses models at $15^{\text {th }}$ April,2010.

* Relative humidity was measured at the height of plant canopy.

\section{Growth of chili pepper under different greenhouse ventilation gaps:}

3.1. Growth response: Data was recorded at the middle stages of the experimental period (40 days after transplanting) in plant height, stem diameter, leaf area and dry matter weight. The growth rate of chili pepper grown in different sized poly-greenhouse ventilation gaps and open field conditions is shown in Table (2). 
Table (2): Growth rate of chili pepper grown under different sized polygreenhouse ventilation gaps on Fayoum, Egypt.

\begin{tabular}{|c|c|c|c|c|c|}
\hline \multirow{2}{*}{ Treatments } & \multirow{2}{*}{$\begin{array}{l}\text { Plant } \\
\text { height } \\
(\mathrm{cm})\end{array}$} & \multirow{2}{*}{$\begin{array}{c}\text { Stem } \\
\text { diameter } \\
(\mathrm{mm})\end{array}$} & \multirow{2}{*}{$\begin{array}{l}\text { Leaf area } \\
\quad\left(\mathrm{cm}^{2}\right)\end{array}$} & \multicolumn{2}{|c|}{ Dry matter weight $(\mathrm{g})$} \\
\hline & & & & Stem & Leaf \\
\hline $\mathrm{T} 1$ & $50.8 \mathrm{bc}$ & $5.7 \mathrm{c}$ & $.986 \mathrm{c}$ & $2.3 \mathrm{c}$ & $4.3 \mathrm{c}$ \\
\hline $\mathrm{T} 2$ & $56.3 \mathrm{~b}$ & $6.4 \mathrm{a}$ & $1.12 \mathrm{ba}$ & $2.5 \mathrm{~b}$ & $5.8 \mathrm{ab}$ \\
\hline $\mathrm{T} 3$ & $58.9 \mathrm{a}$ & $6.6 \mathrm{a}$ & $1.54 \mathrm{a}$ & $3.2 \mathrm{a}$ & $6.1 \mathrm{a}$ \\
\hline $\mathrm{T} 4$ & $53.4 \mathrm{c}$ & $6.3 \mathrm{~b}$ & $1.06 \mathrm{~b}$ & $2.4 \mathrm{~b}$ & $5.2 \mathrm{~b}$ \\
\hline T5 & $42.7 \mathrm{~d}$ & $5.1 \mathrm{bc}$ & $.824 \mathrm{~d}$ & $2.2 \mathrm{c}$ & $4.1 \mathrm{~d}$ \\
\hline
\end{tabular}

Means within a column followed by the same letter are not significantly different by Duncan's multiple range tests at a 5\% level.

Of all poly-greenhouse treatments, the poly-greenhouse with ventilation gaps in the triangular roof and four sidewalls (T3) gave the best growth rate in terms of plant height, leaf area and fresh weight, followed by that of four sides covered with $25 \%$ black screen shade net sheet and the entire roof covered with UV-film sheets (T2), fourth treatment (T4), first treatment (T1) and the open field condition, in descending order. The result suggests that $\mathrm{T} 3$ and $\mathrm{T} 2$ were the most favorable environments for chili pepper production, the result of adequate quantity of transmitted solar radiation, suitable temperatures for plant assimilation, and other environmental factors. However, appropriate cultivation techniques are also needed for the high growth rates of plants, to minimize the adverse effects of climate. Generally, under any type of poly-greenhouses, environment should be partially controlled through opening and closing of the greenhouse doors during the day-time to facilitate proper ventilation for favoring the crop growth.

3.2. Branching and canopy structure: Characteristically, after chili pepper bushes have reached the $8-10$ leaf stage, they begin to develop two branches at every branch node on the main stem. It is possible to judge the growth stage of chili pepper by counting the number of branch nodes and observing the canopy growth. 
Table (3) shows the branching and canopy growth of chili pepper at 40 days after transplanting. It's clear that, the length of the main stem before branch divergence was longest in chili pepper grown under the poly-greenhouse with ventilation gaps in the triangular roof and four sidewalls (T3), followed by that grown in the greenhouse with four sides covered with $25 \%$ black screen shade net sheet and the entire roof covered with UV- film sheets (T2), because of the better environmental conditions. No differences in the rate of aborted branches and canopy width were observed in the various types of poly-greenhouse models at an early stage of canopy formation, but little differences in canopy growth emerged over time. Three months after transplanting, there was a considerable difference between canopy growth in the poly-greenhouse with ventilation gaps in the triangular roof and four sidewalls (T3), with the highest growth rate, and that in the open field condition, with the lowest growth rate (Table 4).

Table (3): Characteristics of branching and canopy of chili pepper bushes after 40 days of transplanting in various treatments.

\begin{tabular}{|c|c|c|c|c|}
\hline Treatments & $\begin{array}{c}\text { Length of } \\
\text { main } \\
\text { stem }(\mathrm{cm})\end{array}$ & $\begin{array}{c}\text { Canopy } \\
\text { width }(\mathrm{cm})\end{array}$ & $\begin{array}{c}\text { Length of first } \\
\text { branch }(\mathrm{cm})\end{array}$ & $\begin{array}{c}\text { Rate of } \\
\text { Aborted } \\
\text { branches }(\%)\end{array}$ \\
\hline T1 & $18.7 \mathrm{~b}$ & $40.6 \mathrm{a}$ & $4.4 \mathrm{~b}$ & $26.1 \mathrm{a}$ \\
$\mathrm{T} 2$ & $21.6 \mathrm{a}$ & $42.3 \mathrm{a}$ & $5.2 \mathrm{a}$ & $25.6 \mathrm{a}$ \\
$\mathrm{T} 3$ & $22.3 \mathrm{a}$ & $43.2 \mathrm{a}$ & $5.6 \mathrm{a}$ & $25.6 \mathrm{a}$ \\
$\mathrm{T} 4$ & $19.6 \mathrm{~b}$ & $41.4 \mathrm{a}$ & $5.0 \mathrm{a}$ & $26.2 \mathrm{a}$ \\
T5 & $18.1 \mathrm{c}$ & $39.7 \mathrm{a}$ & $4.2 \mathrm{~b}$ & $26.8 \mathrm{a}$ \\
\hline
\end{tabular}

Means within a column followed by the same letter are not significantly different by Duncan's multiple range tests at a 5\% level.

3.3. Light interception by the canopy of chili pepper plant: Light interception by the canopy of chilli pepper bushes is shown in Table (4). A significant difference between the various types of poly-greenhouse models was occurred after one month of transplanting. Three months after transplanting, these differences were less marked, but still significant in some cases. 
Table (4): Canopy and light interception in chilli pepper plants grown under different sized poly-greenhouse ventilation gaps.

\begin{tabular}{|c|c|c|c|c|}
\hline \multirow{2}{*}{ Treatment } & \multicolumn{2}{|c|}{ Canopy area (\%) } & \multicolumn{2}{c|}{ Light interception rate (\%) } \\
\cline { 2 - 5 } & $1^{\text {st }}$ June & $1^{\text {st }}$ July & $1^{\text {st }}$ June & $1^{\text {st }}$ July \\
\hline T1 & $32.8 \mathrm{~b}$ & $48.2 \mathrm{~b}$ & $16.3 \mathrm{~b}$ & $27.5 \mathrm{~b}$ \\
$\mathrm{~T} 2$ & $34.3 \mathrm{a}$ & $55.8 \mathrm{a}$ & $17.2 \mathrm{a}$ & $28.3 \mathrm{a}$ \\
$\mathrm{T} 3$ & $35.8 \mathrm{a}$ & $56.8 \mathrm{a}$ & $17.7 \mathrm{a}$ & $28.9 \mathrm{a}$ \\
$\mathrm{T} 4$ & $31.6 \mathrm{~b}$ & $49.1 \mathrm{~b}$ & $16.6 \mathrm{bc}$ & $27.9 \mathrm{a}$ \\
$\mathrm{T} 5$ & $26.4 \mathrm{c}$ & $44.3 \mathrm{c}$ & $16.1 \mathrm{c}$ & $27.4 \mathrm{~b}$ \\
\hline
\end{tabular}

Means within a column followed by the same letter are not significantly different by Duncan's multiple range tests at a $5 \%$ level.

4. Yield and quality of chilli pepper: Table (5) shows the characteristics of flowering and fruit set in chili pepper plants grown under different sized poly-greenhouse ventilation gaps and open field conditions. It's clear that, chili pepper crops grown in poly-greenhouse with ventilation gaps in the triangular roof and four sidewalls (T3) needed fewer days to reach first flowering (61 days, compared to 67 days in the open field condition), and the days needed for the other treatments lie in between of them. All polygreenhouse treatments had a fairly high rate of fruit set $(86-90 \%)$ compared with that in the open field condition (80\%). The number of days until harvest after flowering had begun was 14 days in the polygreenhouse with ventilation gaps in the triangular roof and four sidewalls (T3) and 17 days in the open field condition.

Table (6) shows the characteristics of chili pepper crops harvested from different sized poly-greenhouse ventilation gaps and open field conditions. The poly-greenhouse with ventilation gaps in the triangular roof and four sidewalls (T3) gave highest value of vitamin C content chili peppers (96.9 $\mathrm{mg} / 100 \mathrm{~g})$, but the lowest value $(67.4 \mathrm{mg} / 100 \mathrm{~g})$ was obtained in peppers harvested from the open field condition. It's clear that, the general characteristics of chilli peppers harvested from the third treatment (T3) were: longer fruit, bigger diameter and higher content of vitamin $\mathrm{C}$ compared to the peppers characteristics harvested from the other greenhouses and open field conditions. 
Table (5): Characteristics of flowering and fruit set of chili pepper plants grown under different poly-greenhouse ventilation gaps.

\begin{tabular}{|c|c|c|c|c|}
\hline Treatment & $\begin{array}{c}\text { No. of days } \\
\text { needed to first } \\
\text { flowering }\end{array}$ & $\begin{array}{c}\text { Flower } \\
\text { shedding } \\
\text { rate }(\%)\end{array}$ & $\begin{array}{c}\text { Fruit } \\
\text { setting rate } \\
(\%)\end{array}$ & $\begin{array}{c}\text { No. of days } \\
\text { needed } \\
\text { to harvesting }\end{array}$ \\
\hline T1 & $64.3 \mathrm{~b}$ & $8.2 \mathrm{~b}$ & $86.2 \mathrm{a}$ & $15.9 \mathrm{bc}$ \\
$\mathrm{T} 2$ & $62.7 \mathrm{c}$ & $5.2 \mathrm{c}$ & $88.8 \mathrm{a}$ & $14.6 \mathrm{c}$ \\
$\mathrm{T} 3$ & $60.9 \mathrm{c}$ & $4.8 \mathrm{c}$ & $89.9 \mathrm{a}$ & $14.2 \mathrm{c}$ \\
$\mathrm{T} 4$ & $64.0 \mathrm{~b}$ & $6.8 \mathrm{bc}$ & $87.7 \mathrm{a}$ & $17.3 \mathrm{~b}$ \\
T5 & $66.8 \mathrm{a}$ & $14.1 \mathrm{a}$ & $80.4 \mathrm{~b}$ & $17.8 \mathrm{a}$ \\
\hline
\end{tabular}

Means within a column followed by the same letter are not significantly different by Duncan's multiple range tests at a 5\% level.

Table (6): Characteristics of chili pepper fruit harvested from different sized poly-greenhouse ventilation gaps.

\begin{tabular}{|c|c|c|c|c|}
\hline Treatment & $\begin{array}{c}\text { Fruit length } \\
(\mathrm{cm})\end{array}$ & $\begin{array}{c}\text { Fruit diameter } \\
(\mathrm{mm})\end{array}$ & $\begin{array}{c}\text { Dry/fresh rate } \\
(\%)\end{array}$ & $\begin{array}{c}\text { Vitamin C } \\
(\mathrm{mg} / 100 \mathrm{~g})\end{array}$ \\
\hline $\mathrm{T} 1$ & $12.4 \mathrm{~b}$ & $17.3 \mathrm{~b}$ & $13.5 \mathrm{~b}$ & $85.2 \mathrm{~b}$ \\
$\mathrm{~T} 2$ & $13.9 \mathrm{a}$ & $18.6 \mathrm{a}$ & $10.2 \mathrm{c}$ & $93.7 \mathrm{a}$ \\
$\mathrm{T} 3$ & $14.0 \mathrm{a}$ & $19.8 \mathrm{a}$ & $8.8 \mathrm{c}$ & $96.9 \mathrm{a}$ \\
$\mathrm{T} 4$ & $13.6 \mathrm{~b}$ & $18.2 \mathrm{~b}$ & $12.6 \mathrm{~b}$ & $89.6 \mathrm{a}$ \\
T5 & $11.8 \mathrm{c}$ & $15.4 \mathrm{c}$ & $18.1 \mathrm{a}$ & $67.4 \mathrm{c}$ \\
\hline
\end{tabular}

Means within a column followed by the same letter are not significantly different by Duncan's multiple range tests at a 5\% level.

\section{CONCLUSION}

1. Fayoum depression has a private climatic condition, where, the great gab data between minimum and maximum ambient temperature during the 24 hours of day, especially during the winter months, so the ventilation un-used during the night hrs.

2. The air temperature inside the poly-greenhouse models was the most important denominate environment parameter affecting the growth rate and yield of chili pepper.

3. It was thus concluded that the growth rate and yield of chili pepper could be increased with the use of UV white plastic film covered in the parallelogram roof and $25 \%$ shade net used in the four side walls and 
triangular portion of roof in the poly-greenhouse (T3).

4. It is also, noticed that the four side walls covered with $25 \%$ shade net and entire roof covered with UV white plastic film greenhouse (T2) can also be taken for cultivation of chili pepper under the environmental conditions of this investigation.

5. Under the previous types of greenhouses, environment should be controlled through opening and closing doors during the day-time to facilitate proper ventilation for favoring plant growth.

\section{REFERENCES}

Abdel-Galil, H. S. and Abo-Habaga, M. M. (2007). Effect of polygreenhouse covering type on germination and growth rate of tomato seedlings. The $3^{\text {rd }}$ Conf.of Sustainable. Agric. Develop. Fac. of Agric., Fayoum Univ., 12-14 Nov., 2007: 63-78.

Abdel-Galil, H. S. and Mourad. R. I. A. (2009). Performance of a polygreenhouse with different shading ratios under Fayoum depression climatic conditions. Egypt J. of Appl. Sci., 14(3B): 830-845.

Anonymous. (2003). Major food and agricultural commodities and producers: Countries by commodity. Online. Food and Agriculture Organization of the United Nations, Economic and Social Department, Statistics Division.

Bagga, S.; Sedano, M.; Jesko, H.; Burgos-Vega, C.; Ortega, J. L. and Sengupta-Gopalan, C. (2010). Biotechnology tools for the future capsicum. The $20^{\text {th }}$ International Pepper Conference: Decades of "Hot" and "Cool" Pepper Research. Department Plant and Environmental Sciences, New Mexico State University, Las Cruces, NM, USA. 12-14 September 2010, pp: 15.

Berke, T. G. and Gniffke, P. (2006). Procedures for chili pepper field evaluation trials. International Cooperators Guide. World Vegetable Center. AVRDC Pub \# 06-674.

Garcia, L. C. (1994). Effect of temperature on seed germination and seedling vigour in cupuacu (Theobroma grandiflorum (Willd. ExSpreng) Schum). Pesquisa Agropecuaria., 29 (7): 1145-1150. 
Giacomelli, G. A. and William, J. R. (2005). Greenhouse covering system, Rutgres Univ., downloaded from: http:// ag. Arizona. Edu/ ceac/ research/ archive/ Hort Glazing. Pdf on 3-30-2005.

Kittas, C.; Bartzanas1, T. and Jaffrin, A. (2003): Temperature Gradients in a Partially Shaded Large Greenhouse equipped with Evaporative Cooling Pads. Bio systems engineering, 85(1):87-94.

Kwon, Y. S. K. and Chun, H. (1999). Production of chili pepper in different kinds of greenhouses in Korea. National Horticultural Research Institute. Rural Development Administration. Suweon 441-440, Korea. http:// www. Agent.org/library/ Eb1478.

Maeglasson. W. B. and Adata I. (1977). High temperature effect on style elongation abscise acid level and tomato fruit set. Australian J. of Plant physiology. 3: 809-817.

Nicole, L. S.; Daniel, J. C.; Chad, M. H.; Steven, A. S. and David, D. (2008). Greenhouse Production of the Famous St. Augustine Hot Pepper, the Datil (Capsicum chinense var.). Proc. Fla. State Hort. Soc. 121: 230-233. 2008.

Sanogo, S. (2003). Chile pepper and the threat of wilt diseases. Online. Plant Health Progress doi: 10.1094/PhP-2003-0430-01-RV.

Shaw, N. L.; Cantliffe, D. J.; Hutchinson, C. M.; Sargent, S. A. and Dinkins D. (2008). Greenhouse production of the famous St. Augustine hot pepper, the Datil (Capsicum chinense var.). Proc. Fla. State Hort. Soc. 121:230-233. 2008.

Singh, S. P. (1997). Principles of vegetables production, $1^{\text {st }}$ Edition, Agrotech Publishing Academy. Udaipur. Pp 60-80.

Smith, P. G.; Villalon, B. and Villa, P. L. (1987). Horticultural classification of peppers grown in the United States. HortScience 22:11-13.

Smith, R.; Hartz, T.; Aguiar, J. and Molinar, R. (2005). Chile pepper production in California. University of California. Divission of Agriculture and Natural Resources. Publication \# 7244.

Wikipedia, the free encyclopedia (2007). Solar greenhouse (technical). http://en.wikipedia.org/wiki/solar_greenhouse_(technical) 
Zapata, C. E.; Robles, V. M. C. and Sanchez, D. G. (2002). Performance of chili pepper (Capsicum annuum L.) under greenhouse conditions in Durango, Mexico. Proceeding of the $16^{\text {th }}$ International pepper Conference. Tampico, Tamaulipas, Mexico. November 10-12, (2002). E-mail: cezapata2@yahoo.com.

\section{الملخص العربيى}

\section{معدل أداء صوبة بلاستيكية ذات فتحات تهوية مختلفة \\ تحت الظروف المناخية للفيوم}

حمدى سالم السيد عبد الجليل*

يهـدف هـا البحـث إلى در اسـة معدل أداء الصـوبة البلاستيكية ذات فتحسات التهويـة المختلفـة

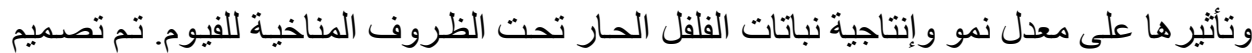

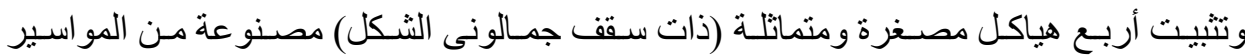

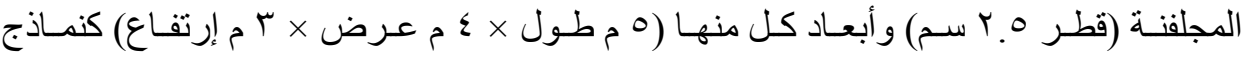

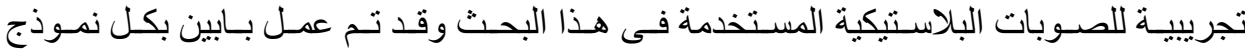

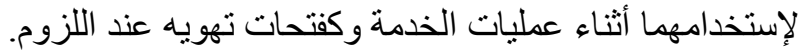
تم تغطية النموذج الأول بغطاء من البولى إيثليلين المقاوم للأشعة فوق البنفسجية فقط للمقارنة بينما تم تغطية الثلاث نماذج الأخرى من الصوبات بنسب مختلفة من البولى البولى إيثيلين المقاوم للأشعة

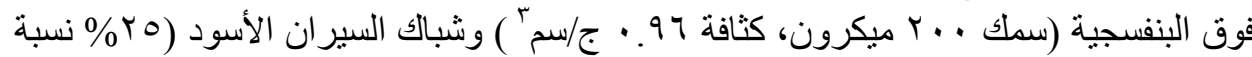
تظليل) وكانت المعاملات المستخدمة فى هذه التجربة على النى النحو التالي:

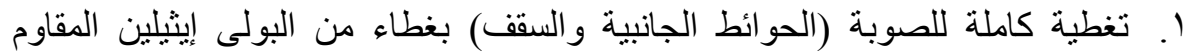

لكأشعة فوق البنفسجية (T1).

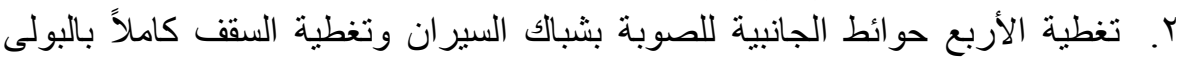
إيثيلين المقاوم للأشعة فوق البنفسجية (T2).

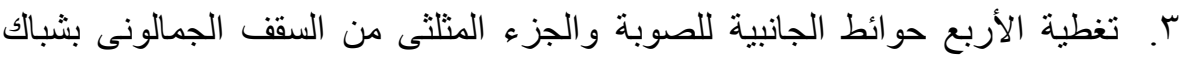
السيران وتغطية باقى السقف بالبولى إيثلين المقاو ملألثعة فوق البعة البنفسجية (T3).

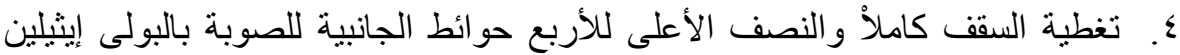
المقاوم وتغطية النصف الأسفل لهذه الحو ائط بشباك السيران الأسود (T4).

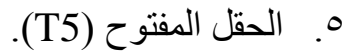

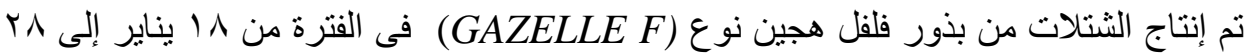

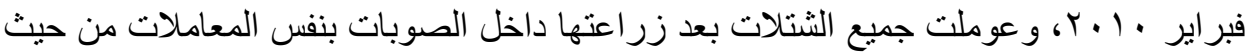
الرى و التسميد و العمليات الزر اعية الأخرى الموصى بها (Nicole et al., 2008). *أستاذ الهندة الزراعية المساعد ـ كلية الزراعة - جامعة الفيوم. 
تم دراسة تأثير شدة الأشعاع الثمسى وفتحات التهوية المختلفة للصوبة البلاستيكية على درجة التهات

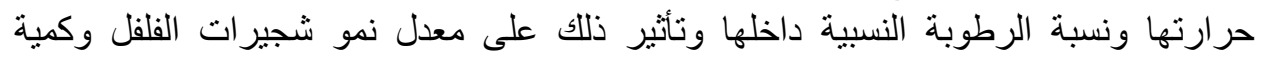

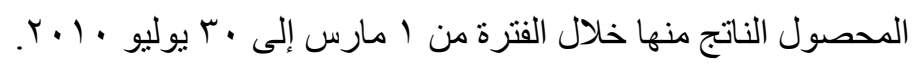

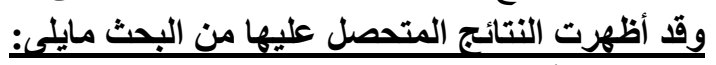

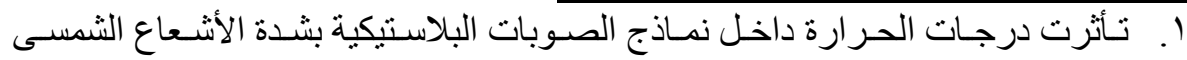

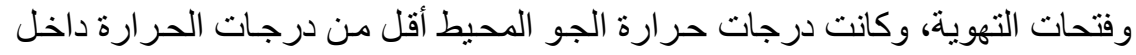

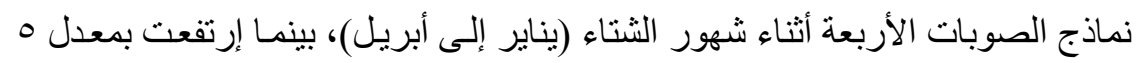

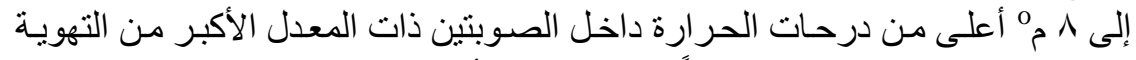

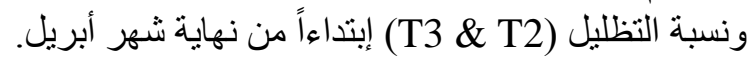

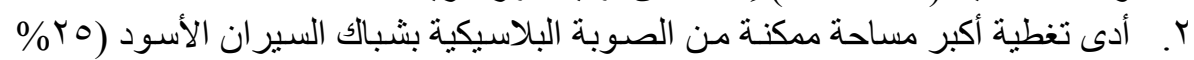

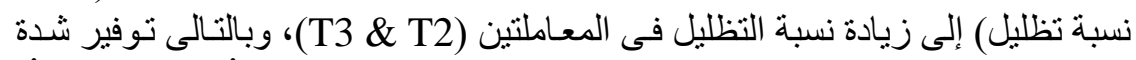

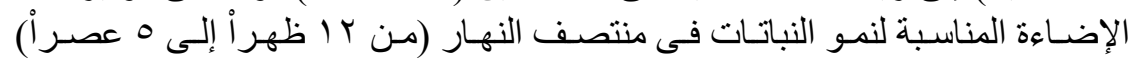

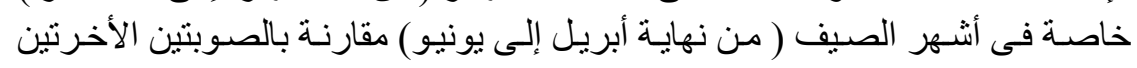

( T1 \& T4)

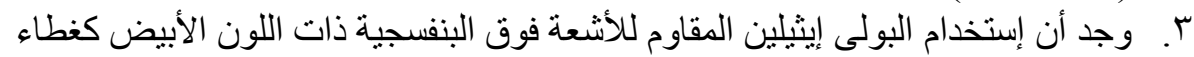

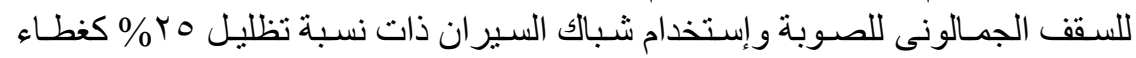

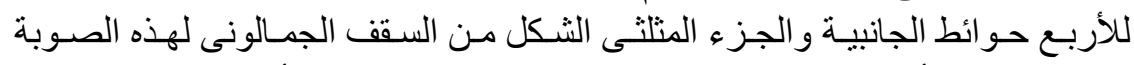

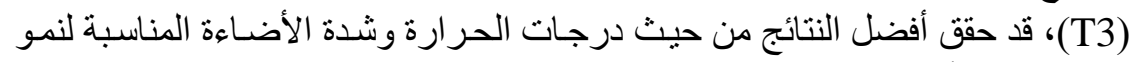

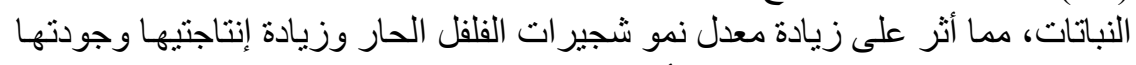

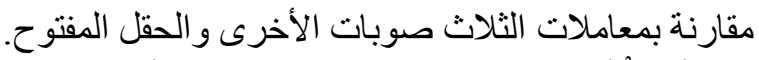

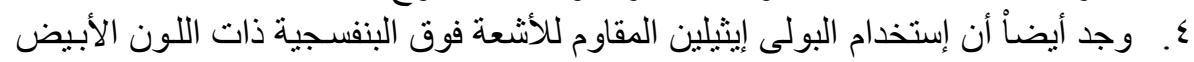

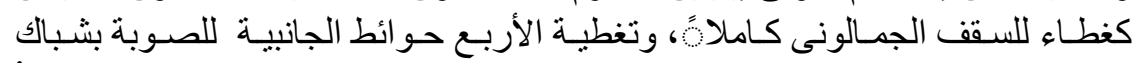

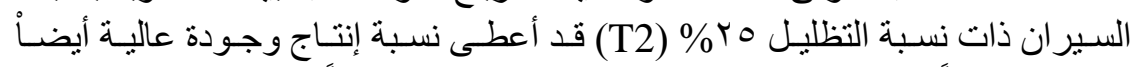

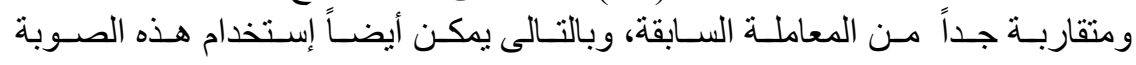

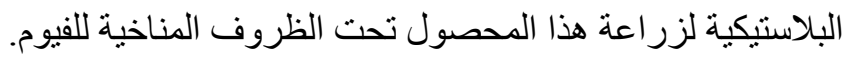

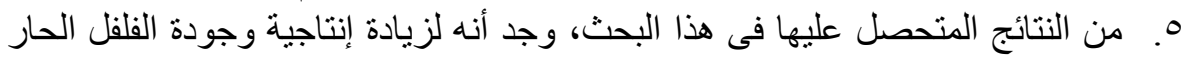

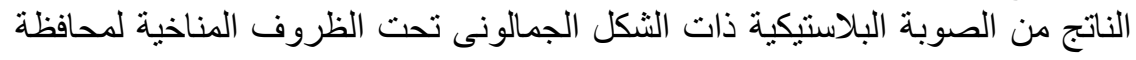

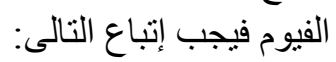

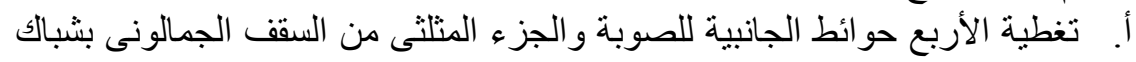
السيران وتغطية باقى السقف بالبولى إيثيلين المقاوم للأشعة فوق البنه البنفجية (T3). أو ب. تغطية الأربع حو ائط الجانبية للصوبة بشباك السبران وتغطية السقق كاملاً بالبولى لئى

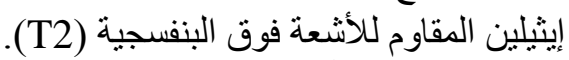
ج. يجب التحكم جزئياً فى الظروف النقاه البيئية داخل الصوبة من خلال فتح و غلق بابيها

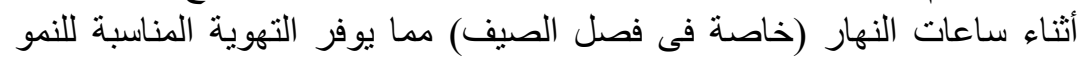

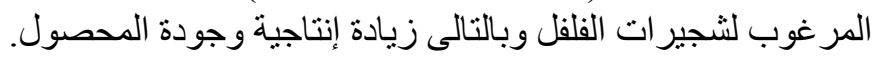

